\title{
London after London
}

\author{
Matthew Beaumont
}

'I have no more faith than a grain of mustard seed in the future history of "civilization", which I know now is doomed to destruction, and probably before very long,' wrote the socialist William Morris in 1885. 'What a joy it is', he added in a tone of vengeful satisfaction, 'to think of barbarism once more flooding the world, and real feelings and passions, however rudimentary, taking the place of our wretched hypocrisies...'

Morris's deliciously intemperate outburst was inspired by After London (1885), a curious novel by the naturalist Richard Jefferies, which depicts a society reshaped by some nameless environmental cataclysm that has almost completely destroyed the British capital. 'This marvellous city, of which such legends are related,' its narrator unsentimentally comments, 'was after all only of brick, and when the ivy grew over and trees and shrubs sprang up, and, lastly, the waters underneath burst in, this huge metropolis was soon overthrown.'

Morris was bewitched by this vision. 'Absurd hopes curled round my heart as I read it', he confided; 'I wish I were thirty years younger. I want to see the game played out.' In a sense, Morris himself played the game out-in the form of News from Nowhere (1890-91), a utopian romance that he set in London approximately a century after a socialist revolution that, in 1952, transformed the nation's social relations. But, compared to After London, there is something rather tame about Morris's pastoral vision of twenty-first century England, which is centred on a series of picturesque descriptions of Bloomsbury. It domesticates Jeffries's fanaticism.

Like Morris, I too have always found the descriptions of the city's destruction that Jefferies included in After London deeply seductive. Indeed, when I see disaster movies in the cinema, I secretly dream about barbarism once more flooding the world. Absurd hopes curl round my heart as I watch entire cities being reduced to rubble by biblical floods and quakes. Because in these ends there is a beginning. The silence of almost empty streets, filmed at first light by the directors of contemporary disaster movies, before the roads and pavements are convulsed by the rhythms of commuters, trembles with utopian promise. 'The post-catastrophe situation,' in Fredric Jameson's formulation, 'constitutes the preparation for the emergence of Utopia itself.'

\section{How to cite this book chapter:}

Beaumont, M. 2013. London after London. In: Bell, S and Paskins, J. (eds.) Imagining the Future City: London 2062. Pp. 169-172. London: Ubiquity Press. DOI: http://dx.doi.org/10.5334/bag.aa 


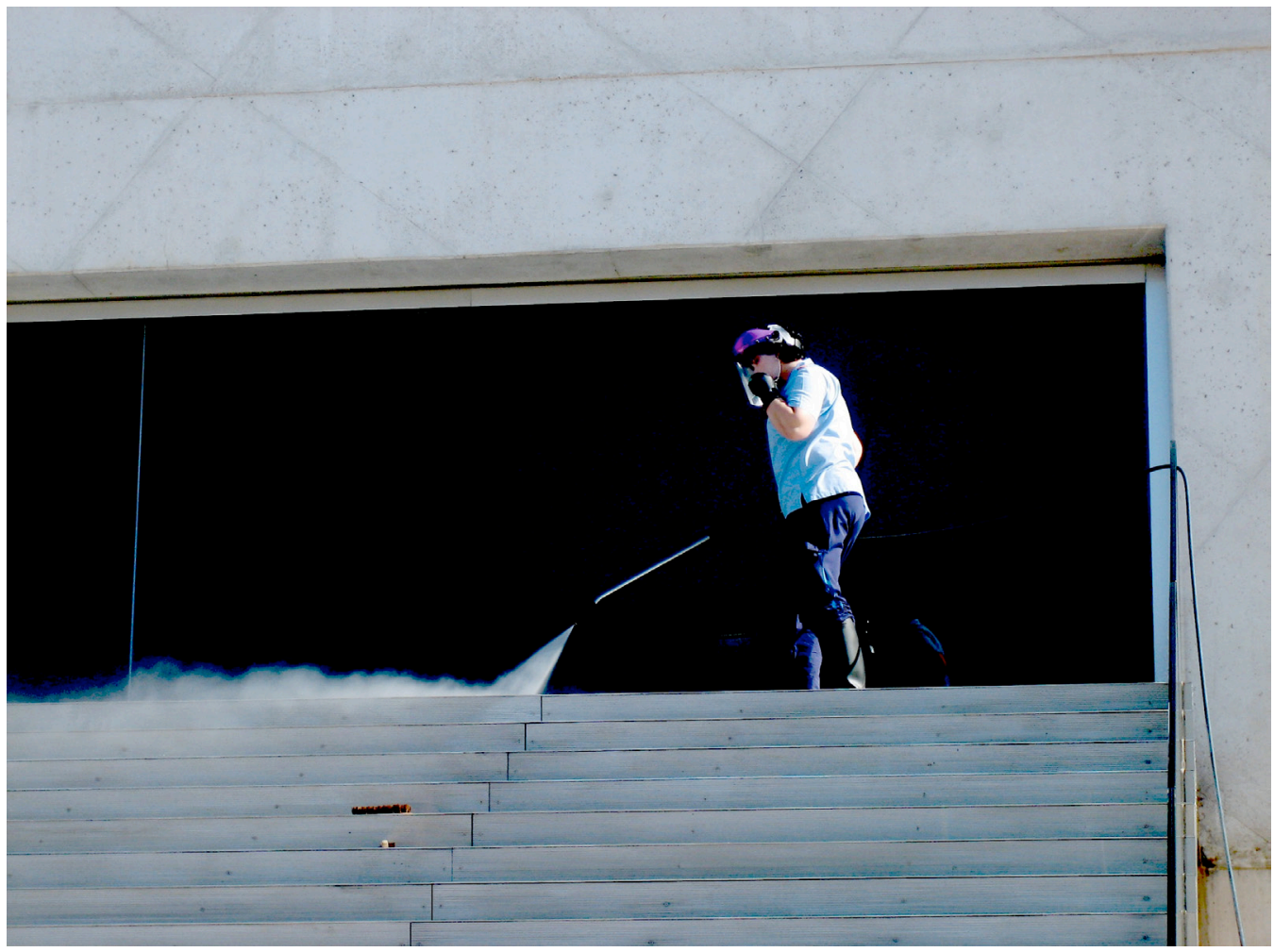

London in 2062 looks like the scene from the archetypal disaster movie in which, in that postcoital calm after the calamity itself, it suddenly becomes obvious that civilisation will have to be totally rebuilt if it is to be saved at all. It is a post-apocalyptic city, one that subsists in the aftermath of an environmental collapse that has rendered the fragile distinction between developed and developing nations quite meaningless. From a distance, it is impossible to decide whether, back in 2012, this city was London, Mumbai or Nairobi. Certainly, the survivors are people of all colours and creeds, and they don't seem to care about their differences.

The city has been scorched and scarified by some unfathomable human accident, possibly caused by a nuclear disaster-though already nobody can exactly remember the first cause. It has been set adrift by floods; honeycombed by bombs; and hurriedly tunnelled out by looters. London's financial district has collapsed into its foundations, and an immense population of computers, chittering like rats, softly decomposes amidst the dust of buildings. 'London, Paris, Tokyo, New York', reads one graffito on the ruined façade of a department store: 'Fission Capitals of the World...'

But centuries of creeping sickness have at least come to an end in these unthinkable seizures, and the city finally seems to be convalescent. Far beneath its pavements lie the fields, forests and streams on which its health had once been founded. A process of forestation is in fact already silently taking place in the metropolis. Emerald-coloured vegetation protrudes with gentle insistence through the cracks that pave the streets. Lichen silently and relentlessly colonizes ancient road signs, like the Xanthoria Parietina that prompts the eponymous character of Patrick Keiller's film Robinson in Ruins to affirm his belief in 'a network of non-human intelligences' which are 'determined to preserve the possibility of life's survival on the planet.' There are even rumours that it is sometimes possible to glimpse zoo animals that, miraculously, have managed to survive in the city in spite of its devastation.

At mealtimes, people collect in the public parks, remnants of the past that suddenly resemble maps of a different future. The people picnic in craters on plants that have been carefully harvested from the cracks and crevices that vein the surrounding roads. Overlooking these scenes, cente- 


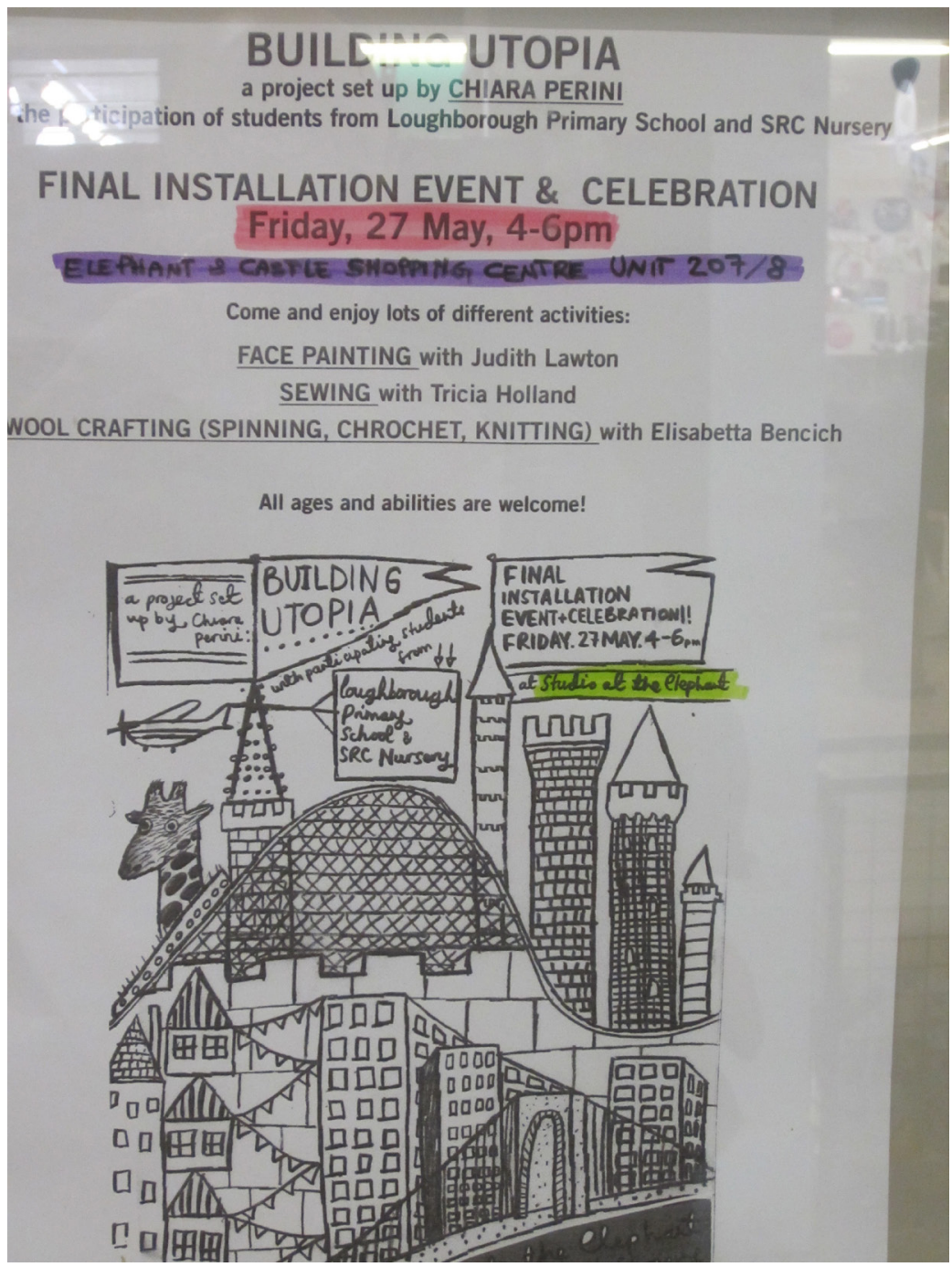

narians recall their long deceased parents' magical descriptions of playing in the ruins of London during the decade after the German air raids, when Rosebay Willowherb, which everybody called 'bombweed', thrived in the cavities and declivities opened up by the shelling. In the 'nonlinear dimensions of urban ecology', to paraphrase Mike Davis, a nonlinear model of history, radiating and proliferating like the ruderals beneath the roads, can faintly be discerned.

The city is excavating itself; it is reconstructing itself. 'The very bones of the city, all her history, from Roman times to the present', are in Michael Moorcock's words 'exposed and clearly visible'. And, among these bones, some of them ancient, people are reimagining the city's musculature. Citizens of all ages and backgrounds are collectively beginning to outline architectural blueprints for fully socialized housing projects, ones that might eventually fulfil the dreams of the twentieth-century avant-garde.

Human beings are starting to rediscover the forms of a communal life they had long forgotten. In spite of the devastation, the city's reclaimed spaces pulse with some dim hope. People collect in the dusty transepts of disused churches or the half-flooded atriums of deliquescent hotels. There they argue, passionately, patiently, about how best to rebuild the metropolis and transform this city of the dead into the city of the future. Real feelings and passions, in Morris's phrase, are finally replacing the hypocrisies we have lived in the name of civilization. 


\title{
It's Malaria Season
}

\author{
Mosquitos breed in the \\ tube tunnels.
}

\author{
Take your medication \\ before entering zone $l$
}

For live outbreak information:

http://londinium.eurorail.com/malaria @LdnMalariaNews

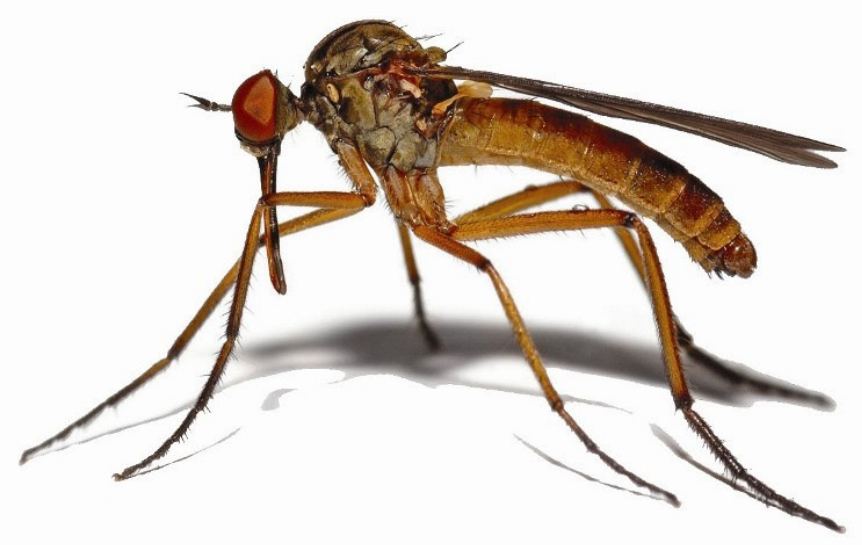

Working together:

euroRail

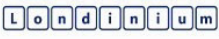

AFRIAID

AFRICAN AID FOR

EUROPE AND NORTH AMERICA
Mayar of

LDNDINIUM

By appointment of

H.R.H King Gearge VII

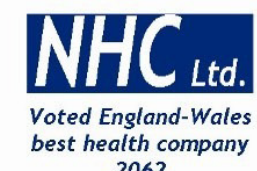

2062 